\title{
THE BENEFITS OF SOCIAL CAPITAL FOR THE WRONGFULLY CONVICTED: CONSIDERING THE PROMISE OF A RESETTLEMENT MODEL
}

\author{
CAROLYN HOYLE and LAURA TILT \\ Carolyn Hoyle is Professor of Criminology, and Laura Tilt is DPhil candidate, Centre for \\ Criminology, University of Oxford
}

Abstract: The Miscarriages of Justice Support Service (MJSS) is the only source of support and assistance provided by the State for the wrongfully convicted. Drawing on original data, this article demonstrates that while its aftercare provision has successfully met the practical needs of the wrongfully convicted, clients have emotional, psychological, and social needs that are not attended to. While the 'rightfully' convicted will be offered services following release from prison to help them to reintegrate into society, those released after the Court of Appeal has found their convictions to be unsafe do not receive such support. Drawing on literature that adopts a resettlement framework for ex-prisoners, the authors argue that such an approach could better respond to the needs of the wrongfully convicted. In particular, this may help the wrongfully convicted to reconnect with social networks, to take advantage of social capital and to thereby rebuild their spoiled identities.

Keywords: resettlement; social capital; trauma; wrongful conviction

Having a home, employment or a vocation, enough money to live comfortably, and mutually supportive relationships are necessary but insufficient conditions for people to function effectively and contentedly in society. It is the somewhat hidden sense of self and sense of 
identity that is key to good mental health and, in particular, to recovery from the trauma of wrongful conviction and imprisonment, a trauma that spoils identities. ${ }^{1}$ Imprisonment, especially for a long time, disrupts life trajectories and the structures that support us: jobs, finances, and families. Prisoners therefore need to rebuild their lives upon release (Appleton 2010; Geest et al. 2016; Liebling and Maruna 2005; Petersilia 2003; Western 2002), being mindful of lost social capital and damaged identities: Sampson and Laub (1993), among others (Becker 1963; Goffman 1963; Kim 2014; Lemert 1967; Pager 2003; Visher and Travis 2003) showed how imprisonment can impact on a person's ability to retain those networks of shared norms, values, and understandings that define and support us and help us to make sense of the world (Stets and Burke 2000). These networks of significant relationships protect and reinforce our shared understandings of the social world in which we live and thereby engender mutual trust, which is vital for our mental health and resilience. Such prosocial networks can be described as 'social capital' (Coleman 1988); they are a powerful resource for those affected by imprisonment (Sampson and Laub 1993). ${ }^{2}$

Individuals accumulate social resources, support, and networks throughout their lives, that enable them to take advantage of opportunities and services within their communities far more easily than they could as isolated individuals (Almedom 2005). Social capital relies on active participation, on the social or moral obligations of members of the network to contribute and support others, so that all can draw on assistance (Bourdieu 1986). As such, networks need to be nurtured and the estrangement from these networks caused by imprisonment, particularly long-term imprisonment, is damaging. In short, absence from our networks, in the physical and emotional seclusion of prison, ruptures our social capital, and while it is most deleterious to the prisoner, it inevitably injures the wider community. As Geest et al. (2016) note: 
Incarceration not only instantaneously interrupts life-course domains such as intimate relations, schooling, and employment, but may also reduce future opportunities to reconnect to these domains ... (p.110)

For the wrongfully convicted, the impact on social capital can be far more destructive as an undeserved penalty and label spoils their identity; it creates a schism between how the world sees them - as an offender - and how they feel - as an innocent person unjustly incarcerated. ${ }^{3}$ Upon release, the wrongfully convicted are left to try to rebuild their lives with the additional burden of trauma caused by that sense of injustice; trauma that impacts on their identity and their trust in others, particularly those thought to represent the State. At the same time, the only support provided by the State - the Miscarriages of Justice Support Service (MJSS) - is not intended to address this emotional and psychological trauma. ${ }^{4}$ Drawing on data collected from the MJSS, this article examines what is offered by the State to the wrongfully convicted, what needs are met by this assistance, and what gaps are left. It then moves on to consider if the needs of the wrongfully convicted would be better met by a resettlement approach.

\section{An Empirical Study of the Miscarriages of Justice Support Service (MJSS)}

The MJSS, established in 2003, is a free and independent advice service operated by 'RCJ Advice', a Citizens Advice service based in the Royal Courts of Justice (RCJ), catering to certain victims of wrongful conviction. The MJSS is the only sanctioned support service for those individuals who fall within its 'remit': those whose convictions have been overturned by the Court of Appeal in England and Wales following a referral by the Criminal Cases Review Commission (CCRC), or those who have been successful in an appeal 'out of time' ${ }^{5}$ in England and Wales. ${ }^{6}$ While functioning as an independent body, the organisation is funded by the Ministry of Justice. Its open contract is renewed every four years, though to date, it has continued to be run by RCJ Advice. ${ }^{7}$ Most clients are referred to the service after a successful 
application to the CCRC in anticipation of their conviction being quashed by the Court of Appeal. Almost all are imprisoned at the time of referral.

We gathered empirical data from the MJSS regarding the nature and impact of the support provided, which also gave us insight into the effects of wrongful conviction. Data were gathered from all 305 client files, current and archived, in and out of remit, since its inception in 2003. Of these files, 93 clients were 'within remit'; that is, the individuals had been convicted of an offence of which they maintained innocence, had a failed direct appeal or number of appeals, and then had their conviction quashed by the Court of Appeal after a referral by the $\mathrm{CCRC}^{8}(90 \%)$ or after an appeal out-of-time (10\%). The remaining files had been closed once it was discovered that they were out of remit; for example, if their convictions were upheld by the Court of Appeal following a reference from the CCRC. Of the 93 clients in remit, 32 did not engage with the service (did not contact the MJSS at all or failed to stay in contact after the initial interview). Of the 61 'engaged service' files, 23 are currently active. Our analysis draws primarily on these 61 cases.

The content of client files varied enormously. The terms and conditions of the MJSS make clear that in order to help clients, the organisation will need to store information about them on the national database provided by Citizens Advice, and that data protection laws require the client to consent to this. However, it says nothing about what data will be gathered: the files we analysed included notes made by the MJSS 'advisor', letters sent by the service to various agencies, applications for benefits, letters from clients to the MJSS, psychiatric assessments, and - in limited cases - prison records. However, incompleteness and inconsistencies in data across the records left gaps in our data. ${ }^{9}$

Drawing on case-file information, we conducted qualitative and quantitative analysis of the demographics of the client base, trends in clients' circumstances or progress, the types of support they received and any positive outcomes (such as remaining in supportive 
relationships, securing jobs, or finding suitable housing). We also sought evidence about client's experiences with the service, including their frustrations, from file records, and sought clarification where necessary from MJSS staff. Data on clients' experiences showed the particular needs of the wrongfully convicted, allowing us to consider whether these are met, and explore what could change in order to provide a more effective aftercare service for the wrongfully convicted. We explore how the MJSS could fit into a wider conceptual framework of 'resettlement' and 're-entry', with reference to the existing literature on prisoners' release following a term of 'rightful imprisonment'.

\section{Our Sample}

Most of the 61 clients who engaged with the MJSS had been wrongfully convicted of a serious crime: the largest proportion (33\%) of our sample for murder; the second, the Importation of 'Class A' Drugs (16\%). Just two of the clients were convicted of a 'white-collar crime'; one for conspiracy to defraud an insurance company, the other for will fraud. Not surprisingly therefore, most clients had received a life sentence. They had spent an average of seven years in prison, with 26 years being the longest time served. Just two had received non-custodial sentences. Most were male (95\%), reflecting the gender distribution of all prisoners (females represent approximately $4 \%$ of the general prison population). ${ }^{10}$ The majority $(72 \%)$ identified as 'White British', with one in five (20\%) being Asian/Asian British, 6\% Black/African/Caribbean/Black British, and 2\% other ethnicity.

\section{The Impact of Wrongful Conviction}

I have lost more than I gained following my release ... ${ }^{11}$

The wrongfully convicted and their families in our study suffered severe financial harms as a result of lengthy periods of imprisonment, but also due to the costs of innocence campaigns. 
By the time their convictions were overturned by the Court of Appeal, they had lost jobs, career prospects, earning capacity, houses, and bank accounts, while accumulating significant debt to family, friends, and financial institutions. On release, they had little to live on and required State benefits. While half of the valid MJSS sample were receiving some benefits prior to the wrongful conviction, almost all (94\%) were in receipt of benefits after their conviction was quashed or they were released from prison (whichever was earlier). Just over a quarter of those in receipt of benefits were receiving jobseeker's allowance.

Wrongful convictions can affect the ability to work and, inevitably, employment prospects. This is partly due to reluctance among employers to recruit ex-prisoners, even when their convictions have been overturned, but also because of deskilling that occurs when people serve long prison sentences, and the physical and psychological impact of long-term imprisonment. ${ }^{12}$ We have employment data on $75 \%$ of those who engaged with the MJSS, showing that just over three-quarters were employed prior to their wrongful conviction; some were in well-paid or high-status jobs, including business, nursing, engineering, and the building trade. However, only a third were employed in some capacity after the wrongful conviction, including $11 \%$ who were employed only for a very limited period. Some were too old to work, but most were psychologically or emotionally unable to work.

The mental health impacts of wrongful convictions can be severe (Wildeman, Costelloe and Schehr 2011). Echoing the research of Dr Adrian Grounds (2004), most of those who had contact with the MJSS reported experiences and clinical diagnoses of post-traumatic stress disorder, depression, anxiety, and apathy. The data showed that the majority of the clients experienced nightmares and flashbacks, which also affected their ability to live with loved ones. Most suffered from paranoia, not just about the police but about people in general. Psychiatric assessment reports, where available, ${ }^{13}$ reported personality change and difficulties in controlling anger among most clients. In many such cases, clients were unable to live with 
others, but at the same time struggled to live alone. The majority seemed to be incapacitated by the trauma of their wrongful convictions and, as such, two-thirds of the valid sample were receiving a disability-related benefit. As one client recounted:

I felt incapable of being a man and taking the lead and at times I wish I was back in prison. This was something I never thought I would feel as a free man. I would often break down in tears and feel that I was in pieces. ${ }^{14}$

Partly due to emotional trauma, wrongful convictions can impact negatively on significant relationships. Almost two-thirds of MJSS clients (61\%) were married or had a cohabiting partner at the time of conviction. By the time their conviction had been overturned, this had dropped to less than a third; a few reported that they still lived with their spouse for practical reasons but were no longer in a romantic relationship. In a letter to one client's GP, requesting a referral to psychiatric counselling, a MJSS psychiatric consultant noted that the client 'lacks the confidence and personal psychological resources to live independently and is therefore prone to relying on others', making clear that while he was not clinically depressed, 'he is anxious and at a loss about how to tackle various practical problems of living' ${ }^{15}$ Clients also had difficulties building and maintaining relationships with other family members, particularly children; many had little or no contact with their children after release. One explained that he had '... difficulty trying to relate to [his daughter] and trying to build a bond or relationship with her. ${ }^{16}$

Psychiatric trauma can have an adverse impact on all relationships but connections with family members and others can be further harmed simply by the passage of time and the consequent strain on family and friendship networks. Without employment or money to engage in social events and other beneficial activities, those who have been released from long prison sentences can have little engagement with social networks, making the maintenance of old, or development of new, relationships challenging. Furthermore, they may have lost touch with 
those still important to their families or not yet be familiar with new people or routines that are meaningful to those they care about. One client described:

The most difficult thing about being out is my relationships with my family. I now do not know where I fit anymore ... Members of my family and my friends will be talking about daily things and its clear they are all talking to people they have known for years. I feel estranged and excluded from this communication. ${ }^{17}$

A MJSS caseworker noted about another client:

The problem is before going into prison he had a lot in common with his wife, now they are different people as the ex-wife is very independent. The client also sees that the only thing he knows about is prison environment, and has nothing else to offer in the way of life experiences. ${ }^{18}$

Much of this difficulty in connecting with others is founded in a deep sense of mistrust. This can leave people lonely, or with just a select few family members or friends with whom they feel secure. As one client said to his caseworker: 'I am afraid of where friendships may lead to and do not want to have friends'. ${ }^{19}$ With little assistance to help regain trust in others, particularly in those in authority, mistrust and fear create barriers to re-establishing support networks. In turn, without such networks, the wrongfully convicted may be perceived as outsiders and shunned or alienated by others, leading to a reinforcing loop of mutual mistrust and fear.

Our data on the impact of wrongful conviction suggests a particularly vulnerable population with multiple needs but often without the social and emotional resources to find ways to meet those needs. While they have specific practical needs, it is the emotional trauma that can impede their resettlement after a period of wrongful imprisonment. By the time a conviction is quashed, many, if not most, wrongfully convicted persons have lost a core part of their identity and have lost their place in society. ${ }^{20}$ In the absence of a job, money, a home, and supportive relationships, they lack a community of support, a sense of purpose, and the 
practical resources to live comfortable and productive lives. Without adequate communication skills, transferable work skills, and other life skills, they can lose their sense of self, feeling that they no longer fit into their pre-conviction world. On top of this, our interviews - particularly with mental health professionals who assess clients at the MJSS for referrals to mental health services and with lawyers who assess clients for compensation applications - suggest that the majority suffer poor mental health as a direct result of being wrongfully convicted and imprisoned (see further, Grounds 2004). Without substantial guidance and support to reestablish their identities and reintegrate effectively into their post-prison world, the wrongfully convicted will feel alone and vulnerable. The following few sections explore how their needs are currently addressed in England and Wales and asks whether more could be done to meet those needs.

\section{Meeting the Needs of the Wrongfully Convicted}

Prior to the inception of an aftercare service for the wrongfully convicted in 2003 , the only option available to assist those whose convictions were quashed was to apply for financial compensation. Evolving case law, ${ }^{21}$ the abolition of an ex-gratia scheme, and new legislation ${ }^{22}$ over the past decade have considerably narrowed eligibility for compensation by restricting it to those cases where 'the new or newly discovered fact shows beyond reasonable doubt that the person did not commit the offence' (Hoyle 2016a). These changes, like cuts to the legal aid budget, are apparently driven by the financial imperatives of a reduced public sector budget and a desire by government to restrict finite public resources to only the most meritorious cases. $^{23}$ Whatever the cause, the result is a vast reduction in the number of successful applications from 39 out of 88 in 2004/05 to just one out of 37 in 2009/10 (Quirk and Requa

2012). Despite legal challenges ${ }^{24}$ numbers have remained very low: just one successful application each year since 2013 (with two in 2015/16) of many tens of applications each year; 
for example, 51 in $2016 / 17 .^{25}$ Given the significantly reduced likelihood of receiving compensation, it becomes ever more pressing that the State offers alternative mechanisms to try to repair some of the harms caused by wrongful convictions and to resettle those released from prison. The MJSS is currently the only service available in England and Wales.

Originally, the MJSS was funded by the Home Office, but since 2008 it has been funded and managed by the National Offender Management Service (NOMS) at the Ministry of Justice, a somewhat surprising 'home' given that those wrongfully convicted who are eligible for its support are recognised as people who have $\underline{\text { not }}$ offended. Before we sought empirical data on what is provided, we were keen to establish what the service is meant to provide; what its remit is. In most government bodies, the remit is established by tender documents. At the time of writing, the grant for 'Advice and support for those released from custody following miscarriage of justice' for 2018 to 2020 was open for tender. ${ }^{26}$ The most recent tender document published by NOMS that is publicly available was produced in 2015. It called for a service that focused on the 'provision of advice and assistance to clients; for example, access to accommodation, social security benefits, local healthcare services and other mainstream provision'. It included 'assistance with practical day-to-day matters, such as opening bank accounts' ${ }^{27}$ Although it made clear that 'individual case work' should be a significant element of the service, it did not require ongoing 'personal contact' and conceded that 'some' communication with clients could be done via telephone or letter. The interpretation of 'some' and the ratio of face-to-face to indirect contact is left to the bidder. Necessary skills of service providers include knowledge and understanding of 'the requirements, both practical and psychological, of victims of miscarriages of justice' and familiarity with processes of government departments (such as those responsible for social security benefits, housing, and mental health). 
At no point does this tender mention 'resettlement', 'reintegration' or 'rehabilitation', as we might see in relation to the general ex-prisoner population (discussed further below). As such, the RCJ Advice and its MJSS, which has successfully bid for the contracts since they were first put out to tender, is not designed nor required to assist with resettlement generally, but only to provide advice and support with practical elements of post-exoneration life, such as housing, benefits, and opening bank accounts. Given that the MJSS is housed, institutionally, within RCJ Advice, it draws on a wealth of experience and organisational relationships. This allows it to outsource information and advice to different areas of resettlement, including housing, benefits, and legal advice, as well as to provide referrals or contacts to address the health and well-being of its clients.

The MJSS has been criticised for its limited scope and inability to provide sufficient assistance to those who have suffered a miscarriage of justice. ${ }^{28}$ However, given the narrow and practical remit of the NOMS ${ }^{29}$ tender, the MJSS successfully fulfils its terms and, in some respects, goes beyond its grant requirements.

Assistance from the MJSS can begin once the CCRC has referred a case to the Court of Appeal, even though about a third of convictions referred by the CCRC are upheld by the Court and the applicant would not then be eligible for support. ${ }^{30}$ Upon referral to the Court, the MJSS is notified and arranges for the client to be contacted for an initial meeting. ${ }^{31}$ This meeting is either conducted in prison, if the individual has not yet been released from a custodial sentence, at their home, or in the MJSS offices. Caseworkers typically run through a checklist of personal and background information with the client to determine their circumstances and needs. If required, housing applications are made at this point in preparation for release to ensure that they are not homeless, as is the case for many ex-prisoners.

The scope of assistance offered by the MJSS is by no means insignificant. Services include assistance with applications for accommodation for those who are homeless (social 
housing or private rented accommodation), for social security benefits (including jobseeker's allowance, employment support allowance, personal independence payments and the new universal credit), for National Insurance credits for time spent wrongfully imprisoned, and for community care grants or crisis loans. Advice is provided on how to register for a GP, find a lawyer to apply for compensation, or receive financial advice in the event they receive compensation. Clients can request advice on training, education, or employment options. In many cases, an MJSS caseworker will assist with family contact procedures, immigration matters, other post-appeal legal advice (including referrals to the Bar Pro-Bono Unit where required), and with opening a bank account or applying for other official identity documents.

Caseworkers liaise between clients, the client's family, and relevant agencies, through email, letters, and telephone, and a helpline is provided for potential or existing clients with concerns or requests for assistance, and to respond to immediate emotional needs to connect with someone who understands their plight: 'a listening ear'. ${ }^{32}$

\section{$\underline{\text { Assistance with Securing Accommodation and Benefits }}$}

Wrongful conviction does not secure priority need status for accommodation. MJSS staff work with clients to make a case for their 'vulnerability' under the statutory test ${ }^{33}$ and to establish in which geographical area they have a 'local connection'. This can be challenging for those who have spent many years in prison and may have become estranged from their prior family and friendship networks. Nonetheless, the MJSS is particularly helpful here. Of those clients in the valid sample who were homeless upon release, almost $80 \%$ were given priority need status for housing following assistance from the service.

The relatively few academic studies conducted to date (in both the US and UK) have demonstrated significant practical and emotional impacts of wrongful conviction, with evidence of physical health problems as well as mental; familial breakdown, estrangement or 
dysfunction; difficulties securing employment; financial troubles; and lasting feelings of mistrust, apprehension and fear (see Campbell and Denov 2004; Grounds 2004; Westervelt and Cook 2012; Wildeman, Costelloe and Schehr 2011). However, those who control public resources want more than a statement that the applicant is a victim of a miscarriage of justice to justify priority housing or benefits. The MJSS helps clients to complete applications, providing evidence of post-traumatic stress disorder or other diagnosable mental health conditions or disabilities. In other words, the caseworker has to fit the client into existing statutory frameworks in order to gain access to essential benefits or services. The evidence must be provided for each separate benefit application and although this is true for all applicants, this is particularly stressful for a newly-released victim of a wrongful conviction who will be constantly reminded of his or her experiences and vulnerability.

Furthermore, despite providing evidence of vulnerability, the MJSS struggles to get their clients accepted by housing associations who have strict criteria in place to limit the provision of social housing. Just recently, a client was given the status of 'priority need', having been homeless for 15 years, four of which he spent living in a mosque. Here the barrier was his marital status: though his marriage had broken down irretrievably, and the MJSS could provide psychiatric evidence which demonstrated that he was unable to live with his wife, he was not divorced, and the housing association refused to give him priority need status as he was legally entitled to occupy the matrimonial home. Such 'by the book' approaches test the resources of the MJSS, their clients and, of course, their families.

Housing associations are under-resourced and the best efforts of the MJSS cannot reduce delays caused by insufficient accommodation. Some clients waiting for permanent housing are offered temporary accommodation, such as 'bed and breakfast'. Most decline, preferring to 'couch-surf' or find temporary shelter with family or friends, fearing that they will be housed with ex-offenders, with the associated stigma that comes with that. 
While almost all (93\% of our client sample) of those who are assisted by the MJSS receive benefits after being released from a quashed conviction, most clients experience frustration at the process of completing numerous similar forms, not least as they are required to reiterate their traumatic experiences for each separate application. MJSS caseworkers often sit with their clients for hours, helping them with this paperwork, tailoring their advice to the particular circumstances of the case and type of application. They typically offer to accompany clients to job centre appointments, and case file notes suggest that this reduces clients' anxieties.

To further assist their clients, the MJSS has formed partnerships with the Department of Work and Pensions to establish a dedicated Employment Support Allowance Unit for its miscarriage of justice clients, and is in negotiations for a similar arrangement in relation to the recently introduced universal credit. This allows their applications to be fast-tracked with fewer delays and less bureaucracy. That said, clients still experience frustrations in applying for social security benefits, and are sometimes unsuccessful, despite presenting an apparently meritorious case. The MJSS assists clients in securing reviews of such decisions, and in the event that the case is taken to a tribunal, will provide or obtain representation. Having this support has proven beneficial, given that the wrongfully convicted typically have little trust in authority, are daunted by the legalese and bureaucracy of the benefits system, and sometimes offended by the insensitivity of those who can deny them support. As one client described in a letter he asked to be made available to potential MJSS clients:

I came out of prison on a Friday and on the Wednesday the Job Centre said I was fit for work. Even though I explained that physically I was fit but mentally I was not as I had just come out of prison after 17 years. The Job Centre said: 'So what, are you fit for work or not?'. I tried to explain that I needed time to adjust and find somewhere to live first. This was ignored and I was refused benefit. When the CAB project was set up a 
year after my release they were able to get my benefits repaid and backdated to the time I was refused.

Providing the wrongfully convicted with advocacy in disputes with statutory authorities is one of the more vital roles of the MJSS, and is appreciated by its clients, as is made clear in this client's letter:

Society as you can imagine is very sceptical about people who say they were innocent. Their attitude is, 'they all say that' and therefore dismiss such claims ... In such situations the $\mathrm{CAB}$ can speak on your behalf and try to ensure you are not discriminated against ...

\section{Proactive Help for Those who Need it, When they Need it}

The MJSS continues to provide support to each client for as long as it is needed, with no time limits imposed on assistance. Clients on the MJSS database have received support for a range of periods of time, from one to 14 years as of 2017, with some cases ongoing: the average being three years. After six months with no contact, the MJSS considers closing the case. A letter is sent to the client informing them of this and providing them with a deadline to respond should they wish their case to remain live. If the service does not hear from the client after the deadline, the case is closed, though the client's file is not destroyed, and - with the client's consent - is archived, and they can have their case reopened should they require support at any point moving forward. In this sense, the MJSS is a reactive, rather than a proactive, service that provides assistance at the specific request of the client. That said, the helpline facilitates easy access to support, and if a caseworker has not heard from a particular client for some time, they will usually contact them, first by phone and then by letter or email.

Research has demonstrated the debilitating effects of wrongful convictions on families (Grounds 2004; Tilt forthcoming), and the MJSS provides 'second-tier' advice and support to 
the families of its clients. Where clients are unable to deal with administrative tasks, family members often assist, sometimes becoming the main point of contact with the MJSS.

\section{$\underline{\text { The Purpose and Limits of Mental Health Assessments }}$}

The MJSS has until recently ${ }^{34}$ drawn on the resources of a dedicated psychiatric consultant with significant expertise in the impact on mental health of wrongful conviction. A third of MJSS clients have been subject to psychiatric assessment for varying reasons but generally for the purposes of establishing need for benefits applications, or demonstrating harms for compensation applications. Most (80\%) assessments were completed within two years following the quashing of their wrongful conviction, but were aimed at making referrals to other services, including for psychiatric treatment, rather than directly providing treatment; the MJSS can only refer clients to mental health specialists through their GP. In other words, clients approaching the MJSS will get practical assistance and a sympathetic response from those who understand something of their clients' experiences, but not direct emotional or psychiatric support. Sometimes practical support and empathy is enough, as one client explained:

It left myself almost with a warmth that there are people (outside my own family) that care enough to help people that have been wronged in this way, that have found themselves firmly planted on the wrong side of the law, and ended up in prison through no fault of their own. ${ }^{35}$

However, most wrongfully convicted people have needs that cannot be met by the MJSS, that the service was not established to respond to.

\section{What's Missing? Addressing the Emotional Needs of the Wrongfully Convicted}

Despite the best efforts of the MJSS, operating effectively within its remit in a time of austerity, and resolving many practical concerns, our data showed that for most of those who are wrongfully convicted some needs remain unmet. In particular, emotional and psychological 
needs, including the need to rebuild a positive self-identity, are not fully addressed, but nor are other needs relating to life skills.

\section{$\underline{\text { Addressing Emotional and Psychological Trauma }}$}

While caseworkers offer some minimal emotional support, the MJSS cannot provide 'in-house' services for mental health problems. Although almost two-thirds (61\%) of the valid client sample was put in contact with, or referred to, an NHS mental health specialist, our data indicate that in most cases, their mental health needs were not met. Many clients were disillusioned with mental health services as they were unable to gain access to tailored psychiatric treatment, despite having been assessed by a psychiatric consultant at the MJSS. Client files expressed frustration among MJSS care workers that despite detailed referrals to psychiatric services for treatment, making clear the particular needs of this client group, psychiatrists lacked the appropriate experience in prison trauma or miscarriages of justice; they simply did not appreciate the effects of imprisonment following a wrongful conviction and failed to provide suitable treatment.

By way of an example, one client who was suffering with poor mental health and had been arrested by the police for breaching the peace, following a public outburst, was admitted into a psychiatric unit. There, he was examined by a locum consultant psychiatrist and 'homeless team' social worker. Despite his past traumatic experiences, both professionals considered his symptoms to be 'exaggerated' and refused to offer him any support services. The discharge summary stated: 'we do not believe his current state warrants crisis intervention even though it is possible he may have some psychological distress secondary to being in prison'. ${ }^{36}$ Soon after, following a 'care and support assessment', ${ }^{37}$ another consultant complained to the MJSS caseworker that the client was aggressive. Neither of these mental health professionals seemed to understand that wrongful imprisonment can result in post- 
traumatic stress disorder, manifesting as anger and frustration (Grounds 2004). A month later, the client attempted to commit suicide.

A psychiatric report conducted for a client in 2012 made no mention of his wrongful conviction, stating that he had a 'conviction for murder which led to ... subsequent years in prison while he appealed against his conviction and then re-trial'. ${ }^{38}$ There was therefore no consideration of the psychological effects of this injustice. Another client was told by a locum doctor to 'put it behind you'. ${ }^{39}$ Not surprisingly, he did not return to a GP after that experience. The apparent lack of knowledge or understanding about miscarriages of justice and their effects within the mental health or counselling professions is disappointing, considering that trauma and other psychiatric conditions are experienced by most wrongfully convicted people. ${ }^{40}$

Inexperience or incompetence among mental health practitioners is, however, only part of the story. Some clients never get as far as a consultation. For many, a lack of trust militates against engagement with professional help. Some may believe that no professional could adequately understand their experiences; one client decided not to enquire with his GP about counselling as he was 'not sure that he would understand exactly what he is saying'. ${ }^{41}$ Another was convinced that his GP had tried to cause him to overdose on medication, as part of a police conspiracy against him. ${ }^{42}$ Such beliefs demonstrate the paranoia that can result from a wrongful conviction. To be effective and accessible, support services must be sensitive to these particular anxieties.

Some clients had to attend substance misuse rehabilitation services and psychiatric treatment designed for a general population, that they felt did not address their particular experiences or concerns. One complained that he 'saw no similarity in my predicament with theirs. Mine was a direct result of imprisonment and it felt unfair to me that Doctor [anonymised] did not see the root of the cause'. ${ }^{43}$ Our research indicated a clear requirement 
for tailored services specifically catering to the wrongfully convicted for most emotional, psychiatric, or behavioural needs.

While it is not within the remit of the MJSS to directly provide psychiatric or emotional support, the lack of tailored services to address these needs can militate against effective provision of practical assistance. Those clients whose mental health problems have not been addressed satisfactorily will be less able to engage with support and assistance to meet their practical needs. If they are depressed or suffering from extreme anxiety, paranoia, agoraphobia, or any one of a number of conditions linked to post-traumatic stress disorder and arising from their experiences of having been wrongfully convicted and imprisoned, they are unlikely to be able to attend appointments for assessment for benefits or housing made on their behalf. They are much less likely to be able to find employment and maintain healthy working, familial, or romantic relationships. In other words, efforts made by the MJSS to help them to rebuild their lives will be much more likely to fail if their mental health is poor. But what of these efforts? How much by way of life-skills support can the MJSS offer within its limited remit?

Our data show that it is not within the remit of the MJSS to provide specific assistance for clients wishing to take advantage of training opportunities or develop skills necessary for employment. While some caseworkers have provided clients with basic advice about employment options upon request, the MJSS does not have the capacity to offer comprehensive guidance on training or support its clients in their search for jobs and in dealing with ongoing difficulties once in employment. Although some clients managed to obtain employment after release, this was often as a result of assistance from family and friends rather than as a result of MJSS service provision. Furthermore, as confidence, social skills, or other life skills, can be impaired by long-term imprisonment, some clients experience considerable difficulties maintaining employment and developing positive relationships with colleagues. An employment report for one client (for the purposes of compensation) indicated that he was 
unlikely to reintegrate into the workforce with 'no assistance or help with ongoing difficulties that cause him problems communicating with others' ${ }^{44}$

MJSS advisors rarely travel to see their clients; generally, this is done only for their initial meeting, and to attend any appointments or hearings. Most contact beyond that is via letter, email, or telephone. While this is sufficient for some clients, and typically allows the MJSS to meet their practical needs, difficulties arising out of problems with reintegration such as settling into a new home or job - are not easily resolved by such contact. Furthermore, support usually ceases once the client has obtained housing but, in such cases, their resettlement is not necessarily complete. For example, one client secured a council flat but wanted to relinquish it because: '.. after living in a cell and with others, it was very difficult to live on his own'. ${ }^{45} \mathrm{He}$ had also received temporary housing a few months after release but 'at that point I did not feel able to take on the responsibility of getting it up and living in it alone. It felt like prison'. Comments such as this reveal the need for a long-term, hands-on approach to more effectively assist these vulnerable individuals to settle after re-entering the community, given that resettlement can take years and include numerous setbacks.

The majority of clients in our sample were unemployed and living on benefits, unable to maintain relationships, and had little hope for the future. To return to the question of their social capital, it is clear that their networks had been ruptured. Social capital is not merely shorthand for good relationships; it focuses on the impact of those relationships and networks on a person's quality of life and future prospects. While focusing on the benefits of social capital for communities, rather than just those individuals within communities, we find work by Forrest and Kearns (2001) useful for our purpose of considering the challenges of re-entry for those who were wrongfully convicted. Forrest and Kearns identified eight spheres of social capital: empowerment (having a voice, being involved in processes and decisions that affect a person and being able to take actions to secure a better future); participation (in social events 
and in the workplace); associational activity and common purposes (co-operation in activities and communal projects that further collective interests); supportive networks and reciprocity (individual and organisational co-operation for individual and mutual support and assistance); collective norms and values; trust (among close networks and in State agencies); safety (not being afraid to move freely in public space); and belonging (a feeling of connectedness to others in the network and to a geographical location).

Our data, presented above, make clear that many of the MJSS clients had insufficient social capital. They did not feel empowered; indeed, some did not even feel invested in their own futures. They found participation challenging, some eschewing communication, and even association, with others. While they may hunger for support, they were not yet able to position themselves as supportive of others, even their dependants. While they may approve of the collective norms and values of their past social networks, some felt stuck with a spoiled identity and unable to trust that others would recognise that they shared these same norms and values. They also had difficulty trusting the State or, indeed, any 'authority figures'. They felt palpably unsafe, afraid of, and unconnected, to their geographical, as well as to their social environment. All of this suggests that they would struggle to benefit fully from social capital.

The remit does not require the MJSS to offer assistance on resettlement to provide opportunities for improving social capital; instead, it is obliged only to provide a reactive service to address specific practical needs. Those clients in our database were, in the main, unsettled following their wrongful conviction and struggled to recover from the injustice that had befallen them. They clearly need help to move forward, to build their social capital and try to repair the harms done to their identity, and the government has a moral obligation to provide this support, given its failure to prevent the wrongful conviction (Hoyle 2016b).

\section{The Promise of a Resettlement Framework}


The literature on ex-prisoners draws heavily on the notion of 'resettlement', albeit the focus is on ex-offenders and efforts to encourage desistance. Research provides ample evidence of the struggles of post-imprisonment life, noting the importance of rebuilding social networks, developing a 'pro-social identity' and, in particular, finding employment on release (Appleton 2010; Liebling and Maruna 2005; Petersilia 2003; van der Geest et al. 2016; Western 2002).

Resettlement is fundamentally about 'social integration and acceptance' (McNeill 2004), about rebuilding fractured networks to benefit from social capital. Indeed, Moore (2011) argues that resettlement is 'not a uniform process or a universally agreed end-state but encompasses complex individuated transitions within social structures of differentiated, and unequal, life opportunity' (p.133). Ex-prisoners need to be able to rebuild support networks and assimilate into these networks in order to become functioning and productive members of society (Giordano, Cernkovich and Rudolph 2002; Liem and Richardson 2014; Maruna 2001). These 'resettlement' approaches have shaped models of rehabilitation, ${ }^{46}$ with some arguing that effective resettlement is an obligation of the State. ${ }^{47}$ As Maruna and LeBel (2002) describe:

If re-entry is to be a meaningful concept, presumably it implies more than physically re-entering society, but also includes some sort of 'relational reintegration' back into the moral community. That is, the reintegrated person should be re-accepted as a fullfledged member in and out of the wider community. (p.167)

Such an approach can be seen in the new 'Transforming Rehabilitation' policies in England and Wales which devise resettlement plans for released prisoners, to help with reintegration into post-prison life. In a report on the government's new 'Through the Gate' programme of resettlement services, rolled out in 2014, HM Inspectorate of Probation and HM Inspectorate of Prisons identified the main requirements for resettlement of prisoners: accommodation; access to finance for clothing, food and transport; a 'sense of hope for the future';48 and 'active links to other services that can assist them with other needs, for example substance misuse and 
mental health services'. ${ }^{49}$ Community Rehabilitation Companies and the National Probation Service (for longer-term prisoners, who have typically committed more serious offences) offer assistance with accommodation, employment, benefits, financial and debt issues, as well as support for abuse victims. However, they also provide ex-prisoners with mentors to establish supportive relationships and to build support networks, and other 're-settlement support', including liaison with family members. ${ }^{50}$

While the MJSS can provide most of these practical services for victims of wrongful conviction, the State's substance misuse and mental health services are not currently sufficiently tailored to the specific needs of this vulnerable population and both resources and remit militate against the kinds of support that facilitates social capital. More importantly, though the State has recognised the importance of a 'sense of hope for the future' for exoffenders, no one currently provides the means to achieve this for the wrongfully convicted. It is this support, more than the practical services and assistance, that best fits with the idea of reintegration and re-establishing a positive, pro-social identity, by drawing on social capital.

It is not our purpose to determine whether or not the resettlement services for general ex-prisoners are fulfilling their aims. Rather, we suggest a similar philosophy may be appropriate for those who leave prison following a wrongful conviction. In theory, probation programmes demonstrate the State's commitment to assisting with, and supporting, the resettlement of those released from prison, but only those who have not had their conviction quashed by the Court of Appeal. What then, of the State's obligations to those wrongfully imprisoned after failures in the criminal justice system?

We have demonstrated that the remit imposed on the MJSS denies the wrongfully convicted the same opportunities to resettle and reintegrate into society, to rebuild their shattered lives. While a blanket policy transfer of services for the 'rightfully' convicted to the wrongfully convicted upon release from prison would be insensitive and likely ineffective, we 
suggest that a commitment to a resettlement regime for this population that goes further than the services offered by the MJSS should repair some of the harms. Indeed, the State has an unequivocal obligation to provide such a response.

\section{Towards a Framework of 'Resettlement' for the Wrongfully Convicted}

Resettlement requires moving beyond solely practical measures towards consideration of the harms done to social capital and identity. Academics researching desistance have established the need for identities to be transformed in order for ex-prisoners to reintegrate effectively into society (Giordano, Cernkovich and Rudolph 2002; Liem and Richardson 2014; Marsh 2011; Maruna 2001). In this vein, resettlement for the wrongfully convicted should similarly extend beyond the practical, with support aimed at restoration of social capital and damaged identities to give them hope for the future.

The concept of resettlement is particularly appropriate for the wrongfully convicted, as many were reasonably settled prior to the disruption of their lives brought about by their wrongful conviction: most of our valid sample of MJSS clients were employed, married or in a cohabiting relationship prior to their wrongful conviction, with only a few reliant on State benefits. While many of their practical needs were addressed adequately by the MJSS, some of their emotional needs were not and most clients lacked social capital to the clear detriment of their progress. This final section considers the potential of a framework of resettlement or re-entry, based on 'relational integration'. We suggest that this population needs help to rebuild social capital and re-enter supportive social networks, and that this could help those released from prison following a wrongful conviction to re-establish their prior (unspoiled) identity (Tilt forthcoming) and lead a functional, social life.

Moore (2011) identifies three stages of re-entry into society from a term of imprisonment, based on the building and maintenance of individual resilience and social capital 
or networks of support, which while applicable to the general ex-prisoner population, is a useful framework for exploring how best to resettle the wrongfully convicted. First, ex-prisoners are released and exposed to 'societal re-entry': the physical relocation back into a community and 'the beginning of the psychological and social transition from the control and routine of prison environments to individual responsibility for day-to-day living' (Moore 2011, p.134). Meeting the practical challenges of resettlement at this stage, against the backdrop of institutionalisation, is aided both by social networks as well as the 'range and depth of their personal abilities, skills and capacities' (p.135). Those wrongfully convicted receive a lot of support at this stage from the MJSS.

At the second stage, re-entry moves beyond practical needs towards social integration. This requires evolution, both personally and socially, towards becoming a functional member of society. Essential for this development is the 'process of growing assimilation into those social networks of emotional, psychological and social support that promote social integration' (Moore 2011, p.135). This includes building social capital through processes of bonding, or rebonding (with friends and family); bridging (establishing or re-establishing social connections such as with work colleagues); and linking (with systems of structural power; 'having the capacity to leverage resources, ideas and information from formal institutions beyond the community') (Woolcock 2001, p.72, cited in Moore 2011, p.135).

Such social capital can be the building blocks to a sense of self and social identity. While caseworkers at the MJSS provide some support for family members, their remit does not require them to make considerable efforts to assist with social reintegration and their resources do not allow it; their focus is on the individual, rather than his or her social network, though the two are inextricably linked.

The final stage of successful reintegration 'denotes an achieved level of settled existence within the community ... a deeper sense of belonging and permanence in 
relationships, of psychological, emotional and social attachment' (Moore 2011, p.136) Here, social capital is working as it should and even if 'old' identities cannot be re-established as they once were, given that trauma brings about change, adjusted or new identities are established that work well within the social network. In this reformed social world, the wrongfully convicted can establish a positive personal narrative which receives a more favourable societal reaction and thus - in time - eradicates their spoiled identity (Tilt forthcoming).

Bringing about change, as described by Moore's three phases, requires support to address emotional and psychological needs as well as practical ones. It will often require dedicated and specialised professional psychiatric support, by professionals trained in the effects of wrongful conviction, particularly for those whose development since release has been arrested by post-traumatic stress disorder or related pathologies.

It also requires guidance and assistance to acquire lost skills, to gain employment, and importantly, to help with reintegration into networks. A sensible approach to re-entry following wrongful conviction needs to focus on nurturing social capital, on trying to mend ruptured networks. Improved social capital can enhance the quality of life of all in the network, including their mental and physical health and sense of well-being. While the wrongfully convicted will have specific individual needs that must be addressed, progress for that person is somewhat dependent on the resources on which he or she can draw from their social network, and therefore re-entry assistance must be cognisant of that network and try to assist those closest to the ex-prisoner to facilitate re-entry and to be able to provide appropriate support.

This journey will be different for all, depending on resilience and existing social capital. Hence, there is a need for reactive assistance for as long as the client needs help, as the MJSS currently provides. However, this is insufficient. Loss of social capital leaves the wrongfully convicted afraid, lonely, distrustful, and lacking in confidence. We should not expect people in 
this emotional state to know when, or how, to reach out for help. Personal contact is thought to be essential in probation settings, given the vulnerability of the ex-prisoner population (Shapland et al. 2012). Similarly, resettlement of the wrongfully convicted requires proactive support; the MJSS must reach out and connect with its clients in regular face-to-face meetings, whenever this is possible and for however long it is needed. While effective support can be provided by the third sector, where it has expertise that meets particular needs, the costs for those services, and the administration involved in matching clients to service providers, should be borne by the State. A State that has failed to protect its citizens from wrongful conviction must be obliged to do all that is reasonable to help to resettle them.

\section{Conclusion}

If the State has an obligation to resettle ex-offenders, with support and services provided by the probation service, it surely has an obligation to assist in the resettlement of those it has wrongfully convicted. A resettlement model that takes seriously the importance of social capital to help rebuild spoiled identities could provide a better mechanism for addressing the post-release needs of the wrongfully convicted, than the current more minimalist, practical approach offered by the MJSS.

While individual caseworkers do their best, the remit imposed by the government restricts the services to mainly practical assistance that is not likely to be successful for those clients who need much more by way of psychological, emotional, and social support, in order to take advantage of the practical resources available. Social capital is protective as well as nurturing. It provides informal support as well as opportunities for making the most of resources available within society more widely. Hence, it can help with employment, with assistance for families, with gaining access to State provisions as well as those available from civil society. It improves health and well-being and as such - in the long term, it can reduce 
reliance on State resources. In other words, if the State helps the wrongfully convicted to reconnect with social networks, and draw on social capital, it will, in the long term, reduce the reliance of the wrongfully convicted on State assistance. Hence, we recommend State-funded support that is more proactive than that currently provided by the MJSS, that provides dedicated mental health services in addition to all the practical services, but that also helps the wrongfully convicted to connect with potentially supportive social networks and to facilitate the development of social capital. This could be provided by mentoring programmes, by far more face-to-face support, counselling, and befriending, and by building relationships with client's families.

We cannot simply ask the existing probation services to take on this new client group. While the resettlement framework can be a helpful starting point, we must be cognisant of the particular vulnerabilities and needs of the wrongfully convicted. MJSS clients in our sample made clear that they did not wish to be seen as a subgroup of the 'rightfully' convicted; for example, they do not want to be housed with ex-offenders or treated as if they had the same needs. In rebuilding their spoiled identities, they need to be seen as distinct, not as people who have caused harm to the State, but as people harmed by the State.

Shadd Maruna's (2001) research on how ex-convicts reform and rebuild their lives makes clear that those who do well, and desist from crime, have been able to construct potent narratives to help them make sense of their pasts, find satisfaction in constructive behaviours, and take control of the direction of their future lives. This is hard to do alone. Moving forward requires the encouragement and support of others; in particular, it needs significant others to believe that progress is possible. Those who have been wrongfully convicted and imprisoned need this too, probably even more. The current aftercare service for the wrongfully convicted needs to expand and develop to ensure that it can provide appropriate mental health support 
and help with all aspects of resettlement to give the wrongfully convicted the best chance of benefiting from social capital and leaving behind their spoiled identities. ${ }^{51}$

\section{Notes}

${ }^{1}$ We do not make a case in this article for how wrongful convictions result in 'spoiled identities', focusing instead on social capital, but rather take as a given that the literature on wrongful convictions (referred to throughout) provides ample evidence of spoiled identities as conceived of by Goffman, and as discussed in the wider literature on crime, justice, and desistance; see, for example, Goffman (1963); Opsal (2012); Paternoster, Bachman and Kerrison (2016). Tilt (forthcoming) further explores spoiled identities.

${ }^{2}$ See also Zamble and Quinsey (1997); for a review of the literature on social capital in prison, rather than on release, see Lafferty et al. (2015).

${ }^{3}$ See, for example, Grounds 2004; Jenkins 2014; Wildeman, Costelloe and Schehr 2011.

${ }^{4}$ Tilt (forthcoming) explores the impacts of wrongful conviction on identity and how the State attempts to repair that harm.

${ }^{5}$ For further discussion on out-of-time appeals, see Taylor (2002).

${ }^{6}$ The service can also assist those who are successful at direct appeal; this 'second-tier assistance' is limited to the same advice and support as could be received by anyone who visits any Citizens Advice Bureau.

${ }^{7}$ In recent years, RCJ Advice has provided grants to seven Local Citizens Advice organisations across the country to continue work with clients once they have settled in an area.

${ }^{8}$ This also includes self-referrals following the quashing of a conviction after a referral from the Home Secretary, that fall within the remit of the MJSS.

${ }^{9}$ Not all client files contained all types of documents, with completeness of data depending on the level of engagement with the service. Where our discussion of the data refers to the "valid sample', it is based only on those cases where that information is known, excluding cases with missing data.

${ }^{10}$ See http://researchbriefings.files.parliament.uk/documents/SN04334/SN04334.pdf (accessed 9 July 2017); see also

https://www.gov.uk/government/uploads/system/uploads/attachment_data/file/585870/omsqbulletin-q3-2016.pdf (accessed 9 July 2017), which could also be used for comparing percentages of wrongfully convicted offences to percentages of offences among the general prison population.

${ }^{11}$ MJSS caseworker notes quoting client (client file).

${ }^{12}$ See, for example, Burnett, Hoyle and Speechley 2017; Garrett 2011; Tilt forthcoming; Westervelt and Cook 2012.

${ }^{13}$ We had incomplete clinical data on the mental health needs of MJSS clients as some had not received psychiatric assessment.

${ }^{14}$ MJSS caseworker notes (client file).

${ }^{15}$ Letter from MJSS consultant to GP requesting client referral to psychiatric services (client file). 
${ }^{16}$ MJSS caseworker notes (client file).

${ }^{17}$ Caseworker notes on telephone conversation with client (client file).

${ }^{18}$ Caseworker notes on call with client, September 2004 (client file).

${ }^{19}$ Caseworker notes (client file).

${ }^{20}$ See, further, Tilt forthcoming.

${ }^{21} \underline{R \text { (Adams) }}$ v. Secretary of State for Justice ([2012] 1 AC 48; [2011] UKSC 18).

${ }^{22}$ Anti-Social Behaviour, Crime and Policing Act 2014, s. 175.

${ }^{23}$ In 2006, the then Home Secretary explained the government's decision to scrap the ex gratia scheme - a move which started the progressive restriction of compensation - in terms that demonstrate this stance, describing: 'A massive industry for the legal profession that has been giving away large amounts of money to individuals who do not deserve it' (quoted in Robins 2014).

${ }^{24} \underline{R \text { (Hallam and Nealon) }}$ v. Secretary of State for Justice ([2016] 3 WLR 329).

${ }^{25}$ We secured these figures by means of a Freedom of Information Act request to the Ministry of Justice in October 2017.

${ }^{26}$ The tender for providing services for 2018-20 closed on 2 January 2018 but the document is not publicly available.

${ }^{27}$ On file with the authors.

${ }^{28}$ See, for example, http://thejusticegap.com/2015/10/walking-free-what-happens-afterconviction-is-quashed-and-the-cell-door-opens/ (accessed 3 June 2017).

${ }^{29}$ NOMS is now known as Her Majesty's Prison and Probation Service (HMPPS).

${ }^{30}$ See https://ccrc.gov.uk/case-statistics/ (accessed 9 July 2017).

${ }^{31}$ In October 2016, changes were made to the information provided by the CCRC to potential applicants to make it clear that if their case is referred for appeal, the CCRC will usually share information with the MJSS to make it easier for the MJSS to offer help once a case is referred: Criminal Cases Review Commission (2017, p.37).

${ }^{32}$ Quoted in caseworker notes (client file).

${ }^{33}$ For the Homelessness Code of Guidance, see https://www.gov.uk/guidance/homelessnesscode-of-guidance-for-local-authorities (accessed 12 June 2017).

${ }^{34} \mathrm{He}$ recently retired, so is no longer able to conduct clinical assessments, though he remains on the MJSS advisory board.

${ }^{35}$ Letter written by client to the MJSS, July 2009.

${ }^{36}$ Discharge summary (client file).

${ }^{37}$ An assessment carried out by a local authority which identifies the care and support needs of an individual, for the purpose of directing that individual to local support services.

${ }^{38}$ Psychiatric report (client file).

${ }^{39}$ MJSS caseworker notes.

${ }^{40}$ Research on the effects of wrongful conviction has identified the emotional and psychiatric harms caused; see, for example, Campbell and Denov (2004); Grounds (2004); Tilt (forthcoming); Weigand (2009); Westervelt and Cook (2012); Wildeman, Costelloe and Schehr (2011).

${ }^{41}$ Caseworker notes (client file).

${ }^{42}$ Initial interview notes with caseworker (client file).

${ }^{43}$ MJSS caseworker notes (case file). 
${ }^{44}$ Employment report, application for compensation (client file).

${ }^{45}$ MJSS caseworker notes (client file).

${ }^{46}$ Rotman (1990, p.183), for example, argues that an offender has a right to an opportunity to return to society, become a useful citizen and stay out of prison - a 'rights' model of rehabilitation.

${ }^{47}$ Cullen and Gilbert (1982) are in favour of State-obligated rehabilitation, that is, the State has an obligation (or moral duty - see Lewis (2005, p.23)) to provide rehabilitative programmes.

${ }^{48}$ See https://publications.parliament.uk/pa/cm201617/cmselect/cmworpen/58/58.pdf (accessed 23 August 2017), p.18.

${ }^{49}$ https://www.justiceinspectorates.gov.uk/cjji/wp-content/uploads/sites/2/2016/09/Throughthe-Gate.pdf (accessed 23 August 2017).

${ }^{50}$ National Probation Service (2016) Operating Model Version 1.0, p.15. Available at: https://www.gov.uk/government/publications/nps-operating-model-version-10 (accessed 23 August 2017).

${ }^{51}$ Acknowledgement: [Do you need to mention the University of Oxford Fell Fund or any other funding?].

\section{References}

Almedom, A.M. (2005) 'Social capital and mental health: an interdisciplinary review of

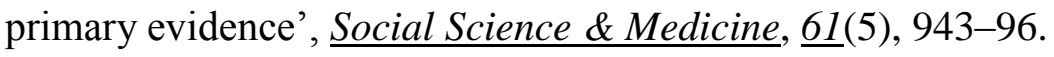

Appleton, C. (2010) Life After Life Imprisonment, Oxford: Oxford University Press.

Becker, H.S. (1963) Outsiders: Studies in Sociology of Deviance, New York: Free Press.

Bourdieu, P. (1986) 'The forms of capital', in: J.G. Richardson (Ed.), Handbook of Theory and Research for the Sociology of Education, Westport, CT.: Greenwood Press.

Burnett, R., Hoyle, C. and Speechley, N.-E. (2017) 'The context and impact of being wrongly

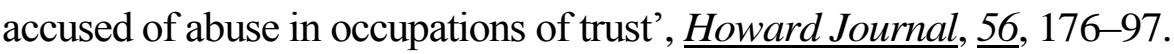

Campbell, K. and Denov, M. (2004) 'The burden of innocence', Canadian Journal of

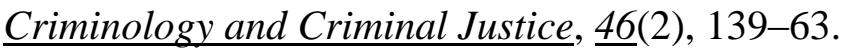


Coleman, J.S. (1988) 'Social capital in the creation of human capital', American Journal of Sociology, 94, S95-S120.

Criminal Cases Review Commission (2017) Annual Report and Accounts 2016/2017, HC 246, London: HMSO.

Cullen, F. and Gilbert, K. (1982) Reaffirming Rehabilitation, Cincinnati, OH.: Anderson.

Forrest, R. and Kearns, A. (2001) 'Social cohesion, social capital and the neighbourhood', Urban Studies, $\underline{38}(12), 2125-43$.

Garrett, B.L. (2011) Convicting the Innocent: Where Criminal Prosecutions Go Wrong, Cambridge, MA.: Harvard University Press.

Giordano, P.C., Cernkovich, S.A. and Rudolph, J.L. (2002) 'Gender, crime and desistance: toward a theory of cognitive transformation', American Journal of Sociology, 107, 990-1064.

Goffman, I. (1963) Stigma: Notes on the Management of a Spoiled Identity, New York, NY.: Simon \& Schuster.

Grounds, A. (2004) 'Psychological consequences of wrongful conviction and imprisonment', Canadian Journal of Criminology and Criminal Justice, $\underline{46}(2), 165-82$. 
Hoyle, C. (2016a) 'Compensating injustice: the perils of the innocence discourse', in: S.M.

Young, J. Hunter, P. Roberts and D. Dixon (Eds.), The Integrity of Criminal Process: From

Theory to Practice, Oxford: Hart.

Hoyle, C. (2016b) 'Victims of the state: recognizing the harms caused by wrongful convictions', in: M. Bosworth, C. Hoyle and L. Zedner (Eds.), Contours of Criminal Justice, Oxford: Oxford University Press.

Jenkins, S. (2014) 'Families at war? Relationships between "survivors” of wrongful conviction and "survivors" of serious crime', International Review of Victimology, 20(2), 243-61.

Kim, Y. (2014) 'The effect of incarceration on mid-life health: a life-course approach', Population Research Policy Review, 34(6), 827-49.

Lafferty, L., Chambers, G.M., Guthrie, J. and Butler, T. (2015) 'Indicators of social capital in prison: a systematic review', Health and Justice, $\underline{3}(7), 1-11$.

Lemert, E.M. (1967) Human Deviance, Social Problems, and Social Control, Englewood Cliffs, NJ.: Prentice-Hall.

Lewis, S. (2005) 'Rehabilitation: headline or footnote in the new penal policy?', Probation Journal, $\underline{52}, 119-35$.

Liebling, A. and Maruna, S. (Eds.) (2005) The Effects of Imprisonment, Cullompton: Willan. 
Liem, M. and Richardson, N.J. (2014) 'The role of transformation narratives in desistance among released lifers', Criminal Justice and Behavior, 41, 692-712.

Marsh, B. (2011) 'Narrating desistance: identity change and the 12-step script', $\underline{\text { Irish }}$ Probation Journal, $\underline{8}, 49-68$.

Maruna, S. (2001) Making Good: How Ex-convicts Reform and Rebuild their Lives, Washington, DC.: American Psychological Association.

Maruna, S. and LeBel, T. (2002) 'Revisiting ex-prisoner re-entry: a buzzword in search of a narrative', in: S. Rex and M. Tonry (Eds.), Reform and Punishment, Cullompton: Willan.

McNeill, F. (2004) 'Desistance, rehabilitation and correctionalism: developments and prospects in Scotland', Howard Journal, $\underline{43}$, 420-36.

Moore, R. (2011) 'Beyond the prison walls: some thoughts on prisoner "resettlement" in England and Wales', Criminology \& Criminal Justice, 12 (2), 129-47.

Opsal, T. (2012) “"Livin' on the straights”: identity, desistance, and work among women post-incarceration', Sociological Inquiry, 82, 378-403.

Pager, D. (2003) 'The mark of a criminal record', American Journal of Sociology, 108, 93775. 
Paternoster, R., Bachman, R. and Kerrison, E. (2016) 'Desistance from crime and identity', Criminal Justice and Behavior, 43, 1204-24.

Petersilia, J. (2003) When Prisoners Come Home: Parole and Prisoner Reentry, Oxford: Oxford University Press.

Quirk, H. and Requa, M. (2012) 'The Supreme Court on compensation for miscarriages of justice: is it better that ten innocents are denied compensation than one guilty person receives it?', Modern Law Review, 75(3), 387-400.

Robins, J. (2014) 'Justice turned upside down: victims of wrongful conviction must prove innocence to get compensation', Shine A Light. Available at: https://www.opendemocracy.net/shinealight/jon-robins/justice-turned-upside-down-victimsof-wrongful-conviction-must-prove-innocenc (accessed 9 September 2017).

Rotman, E. (1990) Beyond Punishment: A New View of the Rehabilitation of Criminal Offenders, New York, NY.: Greenwood Press.

Sampson, R. and Laub, J. (1993) Crime in the Making: Pathways and Turning Points through Life, Cambridge, MA.: Harvard University Press.

Shapland, J., Bottoms, A., Farrall, S., McNeill, F., Priede, C. and Robinson, G. (2012) $\underline{\text { The }}$ Quality of Probation Supervision: A Literature Review, Sheffield: Centre for Criminological Research, University of Sheffield. 
Stets, J.E. and Burke, P.J. (2000) 'Identity theory and social identity theory', Social Psychology Quarterly, 63(3), 224-37.

Taylor, P. (Ed.) (2002) Taylor on Criminal Appeals, Oxford: Oxford University Press.

Tilt, L. (forthcoming) 'The aftermath of wrongful convictions: addressing the needs of the wrongfully convicted in England and Wales' (DPhil thesis, University of Oxford).

van der Geest, V.R., Bijleveld, C.C.J.H., Blokland, A.A.J. and Nagin, D.S. (2016) 'The effects of incarceration on longitudinal trajectories of employment: a follow-up in high-risk youth from ages 23 to 32', Crime \& Delinquency, 62(1), 107-40.

Visher, C.A. and Travis, J. (2003) 'Transitions from prison to community: understanding individual pathways', Annual Review of Sociology, 29(1), 89-113.

Weigand, H. (2009) 'Rebuilding a life: the wrongly convicted and exonerated', $\underline{\text { Public }}$ Interest Law Journal, 18, 427-37.

Western, B. (2002) 'The impact of imprisonment on wage mobility and inequality', American Sociological Review, $\underline{67}(1)$, 526-46.

Westervelt, S.D. and Cook, K.J. (2012) Life After Death Row: Exonerees' Search for Community and Identity, New Brunswick, NJ.: Rutgers University Press. 
Wildeman, J., Costelloe, M. and Schehr, R. (2011) 'Experiencing wrongful and unlawful conviction', Journal of Reoffender Rehabilitation, 50(7), 411-32.

Woolcock, M. (2001) 'The place of social capital in understanding social and economic outcomes', Canadian Journal of Policy Research, 2(1), 11-17.

Zamble, E. and Quinsey, V. (1997) The Criminal Recidivism Process, Cambridge:

Cambridge University Press.

Date submitted: March 2018

Date accepted: June 2018 